\title{
Comparative Studies on the Extraction of Metagenomic DNA from Various Soil and Sediment Samples of Jammu and Kashmir Region in Prospect for Novel Biocatalysts
}

\author{
Singh $\mathrm{R}^{1}$; Devi ${ }^{1} \mathrm{~T}$; Verma $\mathrm{V}^{1}$ and Rasool $\mathrm{S}^{1^{*}}$ \\ School of Biotechnology, Shri Mata Vaishno Devi University, Katra, 182320 \\ Jammu and Kashmir, India
}

\begin{abstract}
A modified and efficient method has been developed for extracting high molecular weight (HMW) DNA free of inhibitors (humic substances) from soil and sediment samples of Jammu and Kashmir region. The method includes precipitation of extracted soil and sediment DNA with 0.5 volumes of $50 \%$ polyethylene glycol (PEG) and 0.1 volumes of $1 \mathrm{M} \mathrm{NaCl}$ (sodium chloride) followed by treatment with $2 \% \mathrm{CaCl}_{2}$ ( calcium chloride).The results of this method were compared with the other reported procedures. The method exhibited good yield and significantly improved the quality of DNA with efficient removal of humic substances. The purity of the extracted DNA from soil and sediment samples was validated by restriction analysis and PCR amplification. DNA extracted from different samples could be purified in one hour with $2 \% \mathrm{CaCl}_{2}$ treatment resulting in DNA pure enough to be processesed for gene cloning techniques. Standard protocol of [9] was used for the extraction of DNA from brackish waters. This paper presents in detail the method which can be used successfully in overcoming the limitation of most of the reported protocols for soil and sediment DNA extraction and purification.
\end{abstract}

Keywords: Brackish, $\mathrm{CaCl}_{2}$, HMW, Humic substances, Metagenome, PCR, PEG 8000

\section{Introduction}

Microbes are the most ubiquitous organisms on earth, represented in all habitats and have a long history as resources for novel enzymes, biocatalysts and biologically active compounds [1]. The concept of microbial diversity has dramatically expanded within the past decade. According to Amann, [2] and colleagues only a minority of the micro-organisms living in any given habitat are cultivable. Amann reported that $0.001 \%$ $0.1 \%$ of the micro-organisms in seawater, $0.25 \%$ in freshwater, $0.25 \%$ in sediments and only $0.3 \%$ of soil microorganisms were found to be cultivable [1] and [3].

Soil is the most diverse of all the naturally occurring microbial habitats with thousands of different microbial species in a few grams. There is a great opportunity for discovering new groups of micro-organisms that would be important for industrial and pharmaceutical research. It is not possible to recreate all of the specific requirements that all soil micro-organisms need, that is why, in addition to standard microbiological techniques, innovative molecular genetics methodologies are being designed and employed [4].By applying these techniques to a given environment, one can obtain large quantities of genetic material and study a vast part of a given microbial community. Hence, soil is, and will continue to be an important source of useful microorganisms awaiting discovery.

Extraction of DNA from soil has enabled the biotechnologists to circumvent the need of culturing indigenous microbiota for metagenomic library construction. In metagenomic analysis the initial step is the isolation of intact, highly pure and high molecular weight (HMW) DNA. However, co-extraction of humic acids and other phenolic compounds is a major problem as they interfere with downstream processing [5].Numerous methods have been recommended to remove humic substances from soil DNA including Cesium chloride density centrifugation [6], Cetyl-trimethyl-ammonium bromide (CTAB),[7], Polyvinylpolypyrrolidone (PVPP), [8] and [9], gel electrophoresis [9] and the Sephadex G- 200 column [10]. However, most of these methods are expensive and some result in reduced DNA recovery [11] and [12].

$70 \%$ of earth's surface is covered with water, which makes it sizeably the largest ecosystem on the planet. Water can provide the most extreme of habitats prevailing on earth. Its temperature can range from -70 ${ }^{\circ} \mathrm{C}$ in the Antarctic glaciers to over $100{ }^{\circ} \mathrm{C}$ in the natural hot springs of Bulgaria [13]. Water bodies are known to harbour an enormous plethora of microbial population, which has previously been ignored for decades. Microbiologists as well as environmentalists worldwide have shown mushrooming interest in the micro biota of the aqueous ecosystem. This makes water a potential reservoir of various bio geochemically active principles, novel enzymes and genes essential for survival [7]. 
In the present study we describe (i) a modified method for soil and sediment DNA extraction and (ii) recommend a new method for removal of humic substances. The objectives of the study were to compare the efficiency of our method with other widely used DNA extraction and purification protocols.

\section{Materials And Methods}

Collection of Soil, Sediment and Water Samples: Different soil, sediment and water samples were collected from different regions of Jammu and Kashmir, in North Western Himalayas, India coded as PTS1 and NTS2 from Patnitop and Nathatop respectively (Longitude 74.85 90'N, Latitude 32.731' 'E) at an altitude of $1500 \mathrm{~m}$ and 2740m respectively, BGS3 and SMVDUS4 from Bhairov Ghati and Shri Mata Vaishno Devi University (Longitude $32^{\circ} 5629^{\prime \prime} \mathrm{N}$, Latitude $74^{\circ} 5714^{\circ}$ 'E) at an altitude of $2650 \mathrm{~m}$ and $754 \mathrm{~m}$ respectively, SedTR lake sediment (Longitude $33^{\circ} 18^{\prime} \mathrm{N}$, Latitude $77^{\circ} 59^{\prime} \mathrm{E}$ ) at an altitude of $4530 \mathrm{~m}$ and SedTM from Tsomoriri lake sediment (Longitude $32^{\circ} 54^{\prime} \mathrm{N}$, Latitude $78^{\circ} 18^{\prime} \mathrm{E} 32.900^{\circ} \mathrm{N}$ ) at an altitude of $4,595 \mathrm{~m}$ respectively. Water samples namely WTR, WTM, WTP were collected from Tsokar, Tsomoriri and Pangong brackish lakes (Longitude $33^{\circ} 43^{\prime} 04.59^{\prime \prime} \mathrm{N}$ Latitude $78^{\circ} 53^{\prime} 48.48^{\prime \prime} \mathrm{E}$ ) at an altitude of 4,350 $\mathrm{m}$ of Ladakh region respectively. The sample collection sites are exposed to wide range of temperatures in different seasons varying between 4 to $30^{\circ} \mathrm{C}$ in summer and -30 to $10^{\circ} \mathrm{C}$ in winter. Approximately $1 \mathrm{~kg}$ of soil and sediment samples were taken from the top $(20 \mathrm{~cm})$ using a sterilized and autoclaved stainless steel knife. Soil and sediment samples were placed in sterilized polyethylene bags and water samples were collected in nalgene screw capped (Thermo scientific; USA) sterilized bottles, placed in ice for transport and stored at $4^{\circ} \mathrm{C}$ for further analysis.

Characteristics of the Soil, Sediment and Water: The moisture contents were determined by drying 1g soil and sediment at $103^{\circ} \mathrm{C}$ for 30 minutes and then calculating the percentage moisture content of the soil and sediment .pH of soil and sediment was measured after diluting the samples in water, using $\mathrm{pH}$ meter. The $\mathrm{pH}$ of water samples was measured by $\mathrm{pH}$ meter.

\section{Optimized Protocol for Soil DNA Extraction}

$5 \mathrm{gm}$ of soil and sediment was mixed with $13.5 \mathrm{~mL}$ of DNA extraction buffer $[100 \mathrm{mM}$ Tris- $\mathrm{HCl}(\mathrm{pH}$

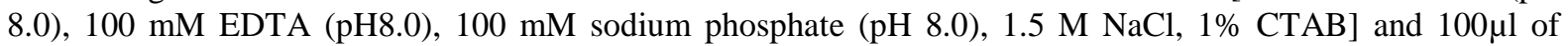
proteinase $\mathrm{K}(10 \mathrm{mg} / \mathrm{mL})$ \} into a sterile $50 \mathrm{~mL}$ centrifuge tube. The tubes were incubated at $37^{\circ} \mathrm{C}$ for 30 minutes with horizontal shaking. $1.5 \mathrm{~mL}$ of $20 \%$ SDS (w/v) was added, and the samples were incubated at $65^{\circ} \mathrm{C}$ for two hours with gentle inversions every 20 minutes. The tubes were centrifuged at $6,000 \mathrm{~g}$ for 10 minutes at room temperature and the supernatant was transferred to fresh $50 \mathrm{~mL}$ centrifuge tubes. The DNA was further extracted (II \& III extractions) by adding $4.5 \mathrm{~mL}$ of extraction buffer and $0.5 \mathrm{~mL}$ of $20 \%$ SDS (w/v) followed by incubation at $65^{\circ} \mathrm{C}$ for $15 \mathrm{~min}$. The tubes were centrifuged at $6,000 \mathrm{~g}$ for $10 \mathrm{~min}$. The supernatants were mixed with an equal volume of Chloroform: Isoamyl alcohol (24:1).The aqueous phase was recovered by centrifugation at $15,000 \mathrm{~g}$ for 10 minutes. The crude DNA was precipitated with 0.5 volumes of $50 \%$ PEG and 0.1 volume of $1 \mathrm{M} \mathrm{NaCl}$ at $-20^{\circ} \mathrm{C}$ for one hour. The tubes were centrifuged at maximum speed and the DNA pellet was washed with 70\% ethanol, dried and dissolved in TE (pH 8.0).

\section{Sediment DNA Extraction}

Several methods were adopted for isolation of DNA from sediment samples (Table 2) and the results were compared with the optimized DNA extraction protocol.

\section{Purification of Soil and Sediment DNA}

Removal of Humic Acid: DNA extracted by the optimized method from soil and sediment was treated with $2 \% \mathrm{CaCl}_{2}$ and left at room temperature for one hour. The samples were pelleted by centrifugation at $15,000 \mathrm{~g}$ for 15 minutes to remove the co-extracted humic compounds. The supernant was collected and the DNA was precipitated with $1 / 10$ volume of $7.5 \mathrm{M}$ ammonium acetate and two volumes of ethanol.The DNA was harvested at 16,000g for 20 minutes at room temperature. The pellet was air dried and resuspended in sterile $1 \mathrm{X}$ TE buffer ( $\mathrm{pH}$ 8.0). The integrity of the DNA was checked on $0.8 \%$ (w/v) agarose gel. The estimations obtained from the gel were then correlated to the readings made by spectrophotometric analysis (UV $3000^{+}$, Labindia Analytical Instruments New Delhi; India).

Alternatively, DNA was also extracted by using different commercially available kits (Ultraclean ${ }^{\mathrm{TM}}$ [Mo Bio Laboratories Inc., Carlsbad, CA, USA], and Hiper ${ }^{\mathrm{TM}}$ Soil DNA kit [Himedia Laboratories., Mumbai, India]) and various recommended protocols with slight modifications in our laboratory, a summary of which is shown in Table 2.

The soil and sediment samples were pre-treated with calcium carbonate and aluminium ammonium sulphate as reported by Sagova-Mareckova et al and the DNA was extracted by bead beating lysis [14].Dong and co-workers protocol of pre-treatment with aluminium sulphate was performed on the soil and sediment with various $\mathrm{pH}$ adjustments [15] and bead beating lysis was used to extract the DNA. 
Modifying the method outlined by Dong et al, we pre-treated the soil and sediment samples with $50 \mathrm{mM}$ each of aluminium sulphate and aluminium ammonium sulphate and post treated the extracted DNA with $100 \mathrm{mM}$ aluminium sulphate. The method of Sagova-Mareckova et al; using calcium carbonate was modified in our laboratory.The DNA extracted by CTAB extraction buffer method [9] was treated with calcium carbonate.The DNA was precipitated with ethanol and dissolved in TE buffer $\mathrm{pH}(8.0)$. DNA extracted by CTAB extraction buffer method [9] was treated with $10 \%$ polyvinylpolypyrrolidone.DNA was precipitated with ethanol and dissolved in TE buffer $\mathrm{pH}$ (8.0). Another modification of DNA extraction protocol by Zhou et al; was made, where we incubated the DNA extracted from $5 \mathrm{~g}$ of soil and sediment with $2 \% \mathrm{CaCl}_{2}$ overnight. The DNA was re- precipitated with ethanol and ammonium acetate and dissolved in TE buffer $\mathrm{pH}(8.0)$.

\section{Water DNA Extraction and Purification}

Approximately 2-5 litres of water collected from different brackish lakes was filtered through $0.45 \mu \mathrm{m}$ and $0.22 \mu \mathrm{m}$ PES membrane filter using a vacuum manifold and the DNA extraction was performed by following [9] protocol without any pre and post modifications. The extracted DNA from water samples was purified by using PCR purification kit (Qiagen; USA)

\section{DNA quantification}

After the purification, DNA was quantified by spectrophotometry with a UV/VIS spectrophotometer (Labindia Analytical Instruments New Delhi; India). The spectrophotometer was calibrated with lambda DNA,non methylated (Bangalore Genei; India).DNA concentration was determined at a wavelength of 260 $\mathrm{nm}$. The absorbance ratio $\mathrm{A}_{260} / \mathrm{A}_{230}$ (DNA/humic acids) and $\mathrm{A}_{260} / \mathrm{A}_{280} \mathrm{~nm}$ (DNA/protein) was used to evaluate the purity of extracted soil, sediment and water DNA .Considering the persistent co-extraction of humic acids from environmental samples we chose 1.5 as the minimum $\mathrm{A}_{260} / \mathrm{A}_{230} \mathrm{~nm}$ ratio for a sample to be called, significantly purified.

A modified and efficient method has been developed for extracting high molecular weight (HMW) DNA free of inhibitors (humic substances) from soil and sediment samples of Jammu and Kashmir region. The method includes precipitation of extracted soil and sediment DNA with 0.5 volumes of $50 \%$ polyethylene glycol (PEG) and 0.1 volumes of $1 \mathrm{M} \mathrm{NaCl}$ (sodium chloride) followed by treatment with $2 \% \mathrm{CaCl}_{2}$ ( calcium chloride).The results of this method were compared with the other reported procedures. The method exhibited good yield and significantly improved the quality of DNA with efficient removal of humic substances. The purity of the extracted DNA from soil and sediment samples was validated by restriction analysis and PCR amplification. DNA extracted from different samples could be purified in one hour with $2 \% \mathrm{CaCl}_{2}$ treatment resulting in DNA pure enough to be processesed for gene cloning techniques. Standard protocol of [9] was used for the extraction of DNA from brackish waters. This paper presents in detail the method which can be used successfully in overcoming the limitation of most of the reported protocols for soil and sediment DNA extraction and purification.

To further validate the purity of extracted soil and sediment DNA by the optimized protocol, and water DNA by [9] procedure, PCR amplification was conducted for all the samples, including a control. PCR was performed in a total reaction volume of $20 \mu 1$ containing $1 \mathrm{X}$ Taq buffer (Bangalore Genei, India), $0.2 \mathrm{mM}$ of each dNTP, template DNA (1:10) diluted, 16S rDNA primers 16Sf [5'-GAATT TGATCCTGGCTCAG-3'] and 16Sr [5'-GGCTACCTTGT TACGACTT-3'] [16] and 1.5U Taq DNA polymerase (Bangalore Genei, India). PCR amplification was performed in a thermo cycler (Bio-Rad, Hercules, CA, USA) The optimized PCR conditions were: Initial denaturation at $94^{\circ} \mathrm{C}$ for 3 mins, 30 cycles of $94^{\circ} \mathrm{C}$ for $30 \mathrm{~s}, 55^{\circ} \mathrm{C}$ for $1 \mathrm{~min}, 72^{\circ} \mathrm{C}$ for $2 \mathrm{~min}$ and a final extension of $72^{\circ} \mathrm{C}$ for 5 mins. The PCR products were subjected to electrophoresis in a $1 \%$ agarose gel containing $1 \mathrm{~kb}$ DNA ladder (Fermentas Life Sciences, Carlsbad, CA; USA)

\section{Restriction enzyme digestion}

Partial restriction digestion of the purified soil DNA samples was performed. DNA was digested with

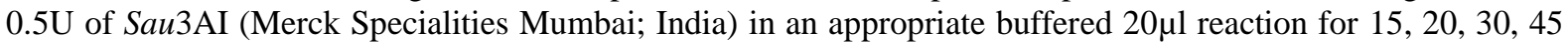
and 1 hour at $37^{\circ} \mathrm{C}$.The enzyme was then heat inactivated at $65^{\circ} \mathrm{C}$ for $5 \mathrm{~min}$ and the digested DNA was resolved in a $1 \%$ agarose gel with EcoRI and Hind III digested lambda DNA ladder (Fermentas Life Sciences, Carlsbad, CA, USA).

\section{Construction of Metagenomic Library}

2-6 kb fragments of partially digested soil metagenomic DNA were ligated into Bam $\mathrm{H} 1$ digested and dephosphorylated $\mathrm{pUC}_{18}$ vector.The ligated products were then transformed into chemically competent E.coli Top 10 cells. The transformation mixture was plated onto LB ampicillin plates containing X-gal (40ug/ml) and IPTG $(50 \mathrm{ug} / \mathrm{ml})$ and the recombinants (white colonies) obtained were grown on LB plates containing $1.5 \%$ starch and ampicillin (100ug/ml). 


\section{Results}

The physico-chemical characteristics of the different soil, sediment and water samples collected from Patnitop, Nathatop, Bhairov Ghati, Shri Mata Vaishno Devi University, Tsokar lake sediment, Tsomoriri lake sediment, Tsokar, Tsomoriri and Pangong brackish lakes of Ladakh region respectively, of Jammu and Kashmir used in DNA extraction study have been listed in (Table 1).Soils were classified as sandy loam, loam, clay and loamy clay. The percentage of the moisture content of the soil and sediment was determined between $32.67 \%$ and $45.2 \%$. The $\mathrm{pH}$ of the soil and sediment ranged from 7.1 to 9.0 . The $\mathrm{pH}$ values of the water samples were in alkaline range (8.8-9.5).

The quality and yield of DNA extracted from $5 \mathrm{~g}$ of soil and sediment samples by different extraction and purification procedures was compared with the optimized protocol (Table 2). Pretreatment with calcium chloride and aluminium ammonium sulphate failed to remove humic substances. Pre-treatment with aluminium ammonium sulphate and ammonium sulphate was not suitable for efficient humic acids removal, however the post treatment of soil samples with aluminium sulphate enabled partial removal of humic substances, but the DNA yield was low.DNA extracted by CTAB extraction buffer method lead to insignificant removal of humic acids along with persistent degradation of DNA. DNA extracted by CTAB extraction buffer method [9] with $10 \%$ polyvinylpolypyrrolidone treatment resulted in no removal of humic content of the samples. In yet another modification of DNA extraction by Zhou et al; protocol DNA extracted was incubated with $2 \% \mathrm{CaCl}_{2}$ overnight however, partial removal of humic acid was seen The highest yield of soil and sediment samples and the most efficient removal of humic acids was observed using CTAB extraction buffer method coupled with PEG/ NaCl precipitation and $\mathrm{CaCl}_{2}$ purification (Fig 1 and Fig 2).An increase in yield and purity of DNA isolated from water samples was observed using Zhou et al protocol. To evaluate DNA purity for enzyme digestion and PCR amplification spectrophotometric analysis was performed, and, $\mathrm{A}_{260} / \mathrm{A}_{230}$ and $\mathrm{A}_{260} / \mathrm{A}_{280} \mathrm{~nm}$ ratios were determined (Table 3). The results indicated that the modified method yielded DNA free of inhibitory humic compounds. In addition, the extraction of soil and sediment DNA by other methods and commercially available kits (Table 2) resulted in low concentration of DNA and inefficient removal of humic acids from the soil and sediment samples.

Qualitative estimation for checking the purity of extracted DNA was analyzed by PCR as well as restriction digestion using restriction enzyme Sau3A1. The extracted DNA was amplified by using $16 \mathrm{~S}$ primers (Fig 4) and the soil DNA was digested without giving any problems (Fig 5a and 5b).

Different soil characteristics correspond to changes in PCR amplification [14]. Sharp amplification of $16 \mathrm{Sr}$ DNA fragments (approx. 1.5kb) was observed when purified DNA samples were used as template. (Fig 4a).

Our aim was to isolate the pure DNA from the soil and sediment samples which could be used for the construction of metagenomic libraries in E.coli.A library of approximately 15,000 colonies was constructed in E.coli using the isolated DNA in $\mathrm{pUC}_{18}$ vector.The library was screened for amylase activity using functional screening assay.

Two clones were found positive among the 15,000 colonies screened so far (Fig. 6). The clones are being further characterized in order to exploit their biotechnology potential.

\section{Discussion}

Theoretically, the microbial DNA, isolated from a soil, sediment and water sample represents the collective DNA of all the indigenous environmental microorganisms [17] and [18]. In a broad range the DNA strategies are separation of cells and direct lysis [19].The main problem when isolating DNA from soil and sediment is co-precipitation of contaminating substances (humic compounds \& phenolics) that interfere with downstream processes[20]. Although there are many methods published worldwide for the extraction of soil and sediment DNA and many commercial kits are available as well, the problem mentioned above is usually encountered in these protocols as physico-chemical properties of soil and sediment vary from location to location.

We started with one of the most accepted methods i.e., CTAB extraction buffer method [9]. The method used the detergents like CTAB and SDS for the direct cell lysis. This method could extract the DNA somewhat efficiently but could not remove the humic acid content. (Table 2). The high content of humic acid could interfere with other processes like PCR amplification and restriction digestion. To remove the humic acids different pre and post treatments with aluminium sulphate, aluminium ammonium sulphate, calcium carbonate and PVPP were given in conjunction with CTAB extraction buffer but humic acid was not efficiently removed. (Table 2). One more method of mechanical lysis by bead beating [5] was also used but the method showed negligible removal of humic acids (Table 2). Most promising method seemed to be extraction by modified CTAB extraction buffer method complemented with 0.5 volumes of $50 \%$ PEG and 0.1 vol of $1 \mathrm{M} \mathrm{NaCl}$ precipitation and purification by one step post treatment with $2 \% \mathrm{CaCl}_{2}$ (Table 2). The role of $\mathrm{CaCl}_{2}$ in purification of the extracted soil and sediment DNA is that it prevents the humic substances, to undergo oxidation forming quinones, which covalently bind to the DNA, thus hampering the DNA and Taq polymerase 
interaction. The gel analysis as well as spectrophotometric analysis showed high concentration of DNA and efficient removal of humic substances (Fig1, 2 and Table 3). Gel analysis of extracted water DNA confirmed Zhou et al 1996 method to be the most suitable protocol for isolation of water DNA from brackish lakes (Fig 3). Inhibition of PCR is often sourced to DNA contaminated with humic acids co-extracted from the soil [18], [23] and [25]. The efficacy of the method described in this paper to remove humic acids was verified by $16 \mathrm{~S}$ rDNA PCR amplification. The purified DNA samples were then successfully partially digested using restriction endonuclease Sau3A1. The restriction digestion was optimised in order to yield 2-6kb fragments.

The protocols optimized in our laboratory worked efficiently on all tested soil, sediment and water types and we were able to construct the soil metagenomic library of approximately 15,000 clones in E.coli. Some of the clones were found positive for amylase activity. (Fig 6).

\section{Figures And Tables}

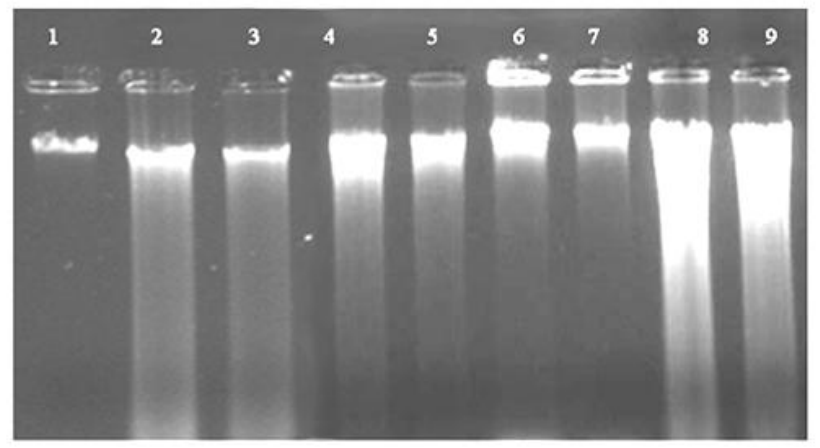

Fig 1: 0.8\% Agarose gel electrophoresis of soil DNA extracted from differ ent soil samples (PTS1, NTS1, BGS3 and SMVDUS4) by PEG and $2 \% \mathrm{CaCl}_{2}$ treatment. Lanes. 1 . Uncut $\lambda$ DNA; 2 . PTS1 PEG precipitated DNA; 3 . PTS1 DNA trented with $2 \%$ $\mathrm{CaCl}_{2}$; 4 . NTS2 PEG precipitated DNA; 5. NTS2 DNA treated with $2 \% \mathrm{CaCl}_{2} ; 6$. BGS3 PEG precipitated DNA; 7 . BGS3 DNA treated with $2 \% \mathrm{CaCl}_{2}$ 8. SMVDUS4 PEG precipitated DNA; 9. SMVDUS4 DNA tr eated with $2 \% \mathrm{CaCl}_{2}$ (All 1 st extraction).

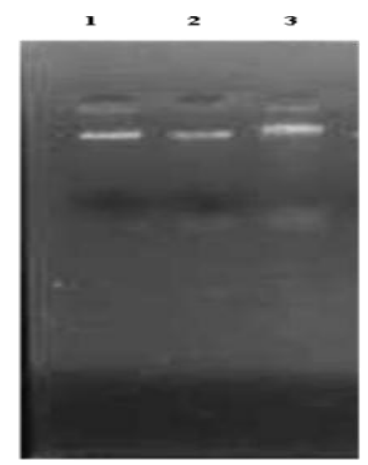

Fig 2: 0.8\% Agarose gel electrophoresis of sediment DNA extacted fiom different sediment samples (SedTR and sedTMI) by2\% CaCly treatment. Lanes. 1. Uncut $\lambda$ DNA; 2 . SedTR DNA treated with PEG + $2 \%$ CaCliz 3. SedTMI DNA treated with PEG + $2 \% \mathrm{CaCT}_{2}$ 


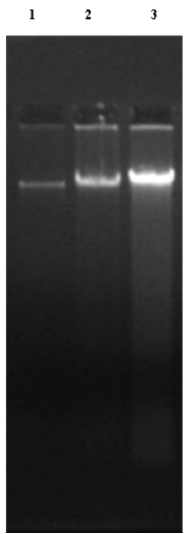

Fig 3: 0.8\% Agar ose gel electrophor esis of water DNA extracted from differ ent Brackish lakes (TWP, TWMI and TWR). Lanes. 1. TWP extracted DNA; 2. TWMI extracted DNA; 3. TWR extracted DNA

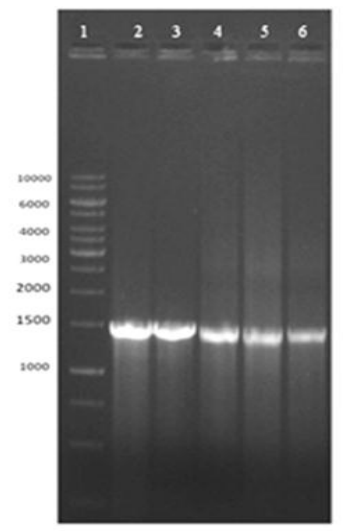

Fig 4 : $1 \%$ Agarose gel showing 16: rDNA amplication products of extractions of PTS1, NTS2, BGS3 and SMNDUS4 DNA with PEG precipitation + CaCl treatment. Lanes. 1. Hb DNA hdder; 2. Control; 3.PTSI soil DNA; 4. NTS2 soil DNA; 5.BGS3 SOIl DNA; 6. SMNDUS4 SOil DNA

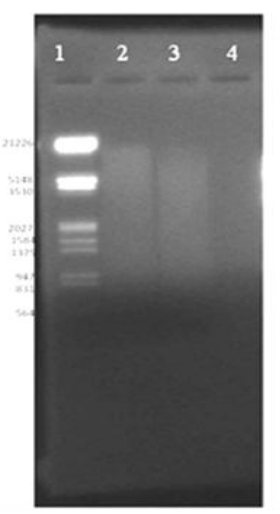

Fig 5(a): 1\% Agaxose gel showing partial restiction digestion of PTSI and NTSZ DNA. Lanes. 1. $\lambda$ DNA cut with ECOR I/FHindIII. 2. SicuB AI digested PTSI DNA (45 mins); 3. SiakB AI digested NTS2 DNA (1H). 


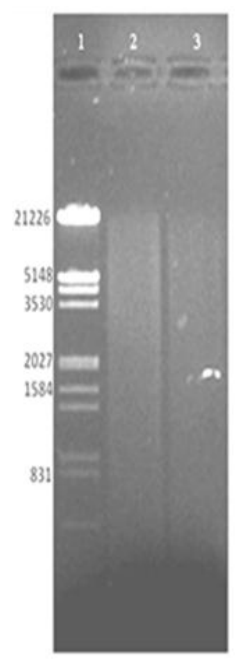

Fig $5(b)$ : $1 \%$ Agarose gel showing partial restriction digestion of BG:S3 and SMTVDUS4 DNA Lanes $1 . \lambda$ DNA cut with ECOR I/FIBAIII. 2.

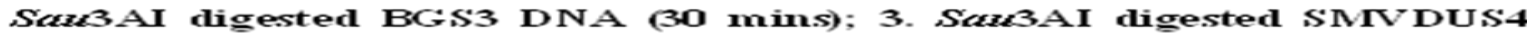
DNA (1Hr).

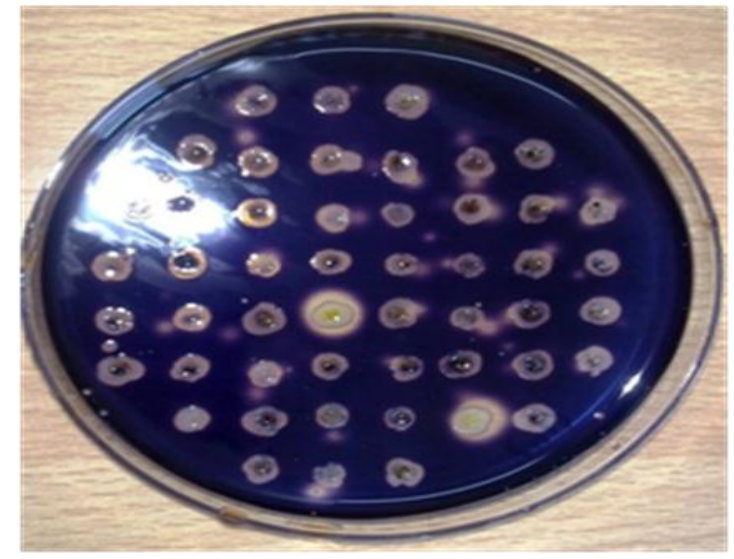

Fig 6: The two positive clones having clear zones of starch hydroly sis around the colonies indicates amylase secretion when flooded with iodine solution.

TABLE 1: Physico-chemical analysis of different soil, sediment and water samples collected from Patnitop, Nathatop, Bhairov Ghati, Shri Mata Vaishno Devi University, Tsokar lake sediment Tsomoriri lake sediment and water samples from Tsokar, Tsomoriri and Pangong brackish lakes respectively of Ladakh region of the state of Jammu \& Kashmir

\begin{tabular}{ccccc}
\hline S.No. & Samples & Texture & Moisture content & $\mathbf{p H}$ \\
\hline 1. & PTS1 & Sandy loam & $35.94 \%$ & 7.4 \\
2. & NTS2 & Loam & $44.4 \%$ & 7.7 \\
3. & BGS3 & Clay & $43.0 \%$ & 7.0 \\
4. & SMVDUS4 & Loamy clay & $32.67 \%$ & 7.1 \\
5. & SedTR & - & $44.4 \%$ & 8.8 \\
\hline
\end{tabular}




$\begin{array}{rrrrr}6 . & \text { SedTM } & - & 45.2 \% & 9.0 \\ 7 . & \text { Turbid } & 100 \% & 8.8 \\ 8 . & \text { WTR } & \text { Clear } & 100 \% & 9.0 \\ 9 . & \text { WTM } & \text { Clear } & 100 \% & 9.4\end{array}$

PTS1: Patnitop Soil, NTS2: Nathatop Soil, BGS3: Bhairov Ghati Soil, SMVDUS4: Shri Mata Vaishno Devi University Soil, SedTR: Tsokar Sediment lake Soil, SedTM: Tsomorriri Sediment Lake Soil, WTR: Tsokar Water, WTM: Tsomorriri Water, WTP: Pangong Water.

TABLE 2: Comparison of various soil and sediment DNA extraction and purification methods

\begin{tabular}{|c|c|c|c|c|}
\hline S.No. & $\begin{array}{l}\text { Method of DNA } \\
\text { Isolation }\end{array}$ & $\begin{array}{l}\text { Modifications } \\
\text { done }\end{array}$ & Results & References \\
\hline 1. & Bead beating lysis & $\begin{array}{l}\text { Pre- treatment } \\
\text { with } \mathrm{CaCO}_{3}\end{array}$ & $\begin{array}{c}\text { Negligible amount of humic acid } \\
\text { was removed. DNA obtained } \\
\text { was sheared. }\end{array}$ & $\begin{array}{c}\text { No modification } \\
\text { S. Marketa. et al;2008 }\end{array}$ \\
\hline 2. & By extraction buffer & $\begin{array}{l}\text { Pre-treatment with } \\
\text { aluminium ammonium } \\
\text { sulphate }\end{array}$ & Humic acid was not removed & $\begin{array}{l}\text { No modification } \\
\text { S. Marketa. et al;2008 }\end{array}$ \\
\hline 3. & By extraction buffer & $\begin{array}{l}\text { Pre-treatment with } \\
\text { aluminium sulphate }\end{array}$ & Low yield of DNA. & $\begin{array}{l}\text { No modification } \\
\text { Dong et al; } 2006\end{array}$ \\
\hline 4. & $\begin{array}{l}\text { Extraction by using } \\
\text { glass beads }\end{array}$ & $\begin{array}{l}\text { Pre-treatment with } \\
\text { Aluminium sulphate } \\
\text { and Aluminium } \\
\text { ammonium sulphate }\end{array}$ & $\begin{array}{c}\text { Low yield of DNA. Humic acid was not } \\
\text { removed }\end{array}$ & Modified Dong et al; 2006 \\
\hline 5. & By extraction buffer & $\begin{array}{l}\text { Post treatment with } \\
\text { aluminium sulphate }\end{array}$ & $\begin{array}{c}\text { Humic acid was partially removed and low } \\
\text { yield of DNA. }\end{array}$ & Modified Dong et al; 2006 \\
\hline 6. & $\begin{array}{l}\text { By CTAB extraction } \\
\text { buffer }\end{array}$ & $\begin{array}{l}\text { Post treatment with } \\
\qquad \mathrm{CaCO}_{3}\end{array}$ & $\begin{array}{l}\text { Negligible amount of humic acid was } \\
\text { removed. DNA obtained was sheared }\end{array}$ & $\begin{array}{c}\text { Zhou. et. al;1996 } \\
\text { Modified S. Marketa. et } \\
\text { al;2008 }\end{array}$ \\
\hline 7. & $\begin{array}{l}\text { By CTAB } \\
\text { extraction buffer }\end{array}$ & $\begin{array}{l}\text { Post treatment with } \\
10 \% \text { PVPP }\end{array}$ & Humic acid was not removed & $\begin{array}{c}\text { Zhou. et. al;1996 } \\
\text { Modified Krsek. et. al;1999 } \\
\text { Nalin et. al } 1999 .\end{array}$ \\
\hline 8. & $\begin{array}{l}\text { By CTAB extraction } \\
\text { buffer }\end{array}$ & $\begin{array}{l}\text { Post treatment with } \\
\text { aluminium ammonium } \\
\text { sulphate }\end{array}$ & Humic acid was not removed & $\begin{array}{l}\text { No modification } \\
\text { Zhou. et. al;1996 } \\
\text { Braid.et. al; } 2003\end{array}$ \\
\hline 9. & $\begin{array}{l}\text { By CTAB extraction } \\
\text { buffer }\end{array}$ & $\begin{array}{l}\text { Overnight Post } \\
\text { treatment with } 2 \% \\
\qquad \mathrm{CaCl}_{2} \text {. }\end{array}$ & Humic acid was not completely removed. & Modified Zhou. et. al;1996 \\
\hline 10. & $\begin{array}{l}\text { Mo Bio Kit, CA, } \\
\text { USA }\end{array}$ & ----- & $\begin{array}{l}\text { Low concentration of DNA Inefficient } \\
\text { removal of humic acids }\end{array}$ & --- \\
\hline 11. & $\begin{array}{l}\text { Hiper Soil DNA } \\
\text { Kit,Himedia,India }\end{array}$ & & $\begin{array}{l}\text { Low concentration of DNA } \\
\text { Inefficient removal of humic acids }\end{array}$ & ---- \\
\hline 12. & $\begin{array}{l}\text { DNA extraction by } \\
\text { using Activated } \\
\text { charcoal. }\end{array}$ & $\begin{array}{c}\text { Treatment with } \\
\text { activated charcoal \& } \\
\text { modified extraction } \\
\text { buffer }\end{array}$ & Low yield of DNA. & D.Verma. et.al;2011 \\
\hline 13. & $\begin{array}{l}\text { DNA extraction by } \\
\text { using glass beads. }\end{array}$ & $\begin{array}{l}\text { Treatment with } \\
\text { sodium phosphate } \\
\text { buffer \& sodium }\end{array}$ & Humic acid not removed & A.Ogram et. al ; 1987 \\
\hline
\end{tabular}




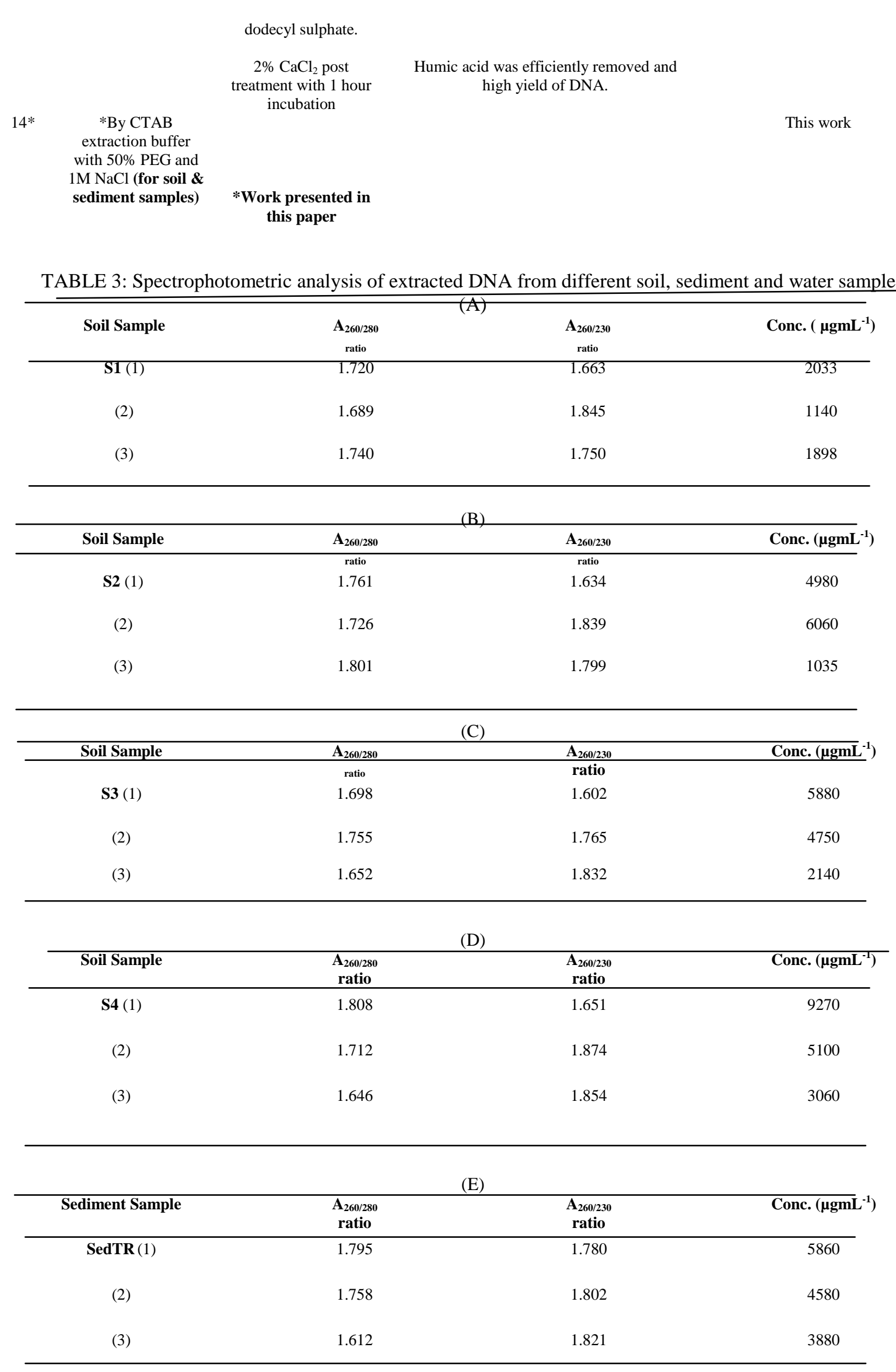


(F)

\begin{tabular}{cccc}
\hline Sediment Sample & $\begin{array}{c}\mathbf{A}_{260 / 280} \\
\text { ratio }\end{array}$ & $\begin{array}{c}\mathbf{A}_{260 / 230} \\
\text { ratio }\end{array}$ & Conc. ( $\left(\mathrm{mgmL}^{-1}\right)$ \\
\hline SedTM (1) & 1.823 & 1.798 & 6020 \\
$(2)$ & 1.720 & 1.814 & 5240 \\
$(3)$ & 1.598 & 1.832 & 4080 \\
\hline
\end{tabular}

\begin{tabular}{|c|c|c|c|}
\hline Water Samples & $\begin{array}{l}\mathbf{A}_{2} \\
\text { ratio }\end{array}$ & $\begin{array}{l}\mathbf{A}_{2} \\
\text { ratio }\end{array}$ & Conc. $\left(\mu g m L^{-1}\right)$ \\
\hline WTR & 1.804 & 1.902 & 4160 \\
\hline WTM & 1.786 & 1.868 & 3220 \\
\hline WTP & 1.818 & 1.894 & 3060 \\
\hline
\end{tabular}

*Work presented in this paper

\section{Conclusion}

Summarily, the soil and sediment DNA extraction and purification method described here, is a simple and efficient method for most of soil and sediment samples. DNA extracted from different samples could be purified in one hour with $2 \% \mathrm{CaCl}_{2}$ treatment, resulting in DNA pure enough to be used for restriction digestion and PCR, as compared to the commercially available kits in the market and other reported methods which resulted in lower concentration of DNA along with only 60-70\% success rate in PCR amplification of the extracted soil and sediment DNA. Thus, the optimized laboratory method yielded higher concentration of DNA free of humic substances enabling us to construct metagenomic library meant for selecting clones that exhibit amyloytic activity.Also, data obtained from water DNA isolation showed an impressive potential of the standard Zhou et al protocol to be used for different water types (brackish water).

\section{Acknowledgement}

*Miss Reena Singh is thankful to Council of Scientific and Industrial Research (CSIR), Government of India for the award of Senior Research Fellowship.

\section{References}

[1] P.Lorenz, and J. Eck, Metagenomics and industrial applications, Nature Reviews Microbiology. 3. $2005,510-516$.

[2] R.I. Amann, W.Ludwig, and K.H. Schleife, Phylogenetic identification and in situ detection of individual microbial cells without cultivation,Microbiological Review.59. 1995, 143-169.

[3] M.S. Rapp'e, J.Stephen, and S.J.Giovannoni, The uncultured microbial majority, Annual Review of Microbiology. 57. 2003,36994.

[4] O.Sprusansky, L. Zhou, S.Jordan, J.White, and J. Westpheling, Identification of three new genes involved in morphogenesis and antibiotic prodcution in Streptomyces coelicolor, Journal of Bacteriology. 185. 2003, 6147-6157.

[5] I.G.Wilson, Inhibition and facilitation of nucleic acid amplification,Applied and Environmental Microbiology. 6. 1997, 37413751 .

[6] L.G.Leff, J.R.Dana, J.V.Arthur, and L.J.Shimkets, Comparison of methods of DNA extraction from stream sediments, Applied and Environmental Microbiology. 61. 1995, 1141- 1143.

[7] J.J. Cole, Y.T.Prairie, N.F.Caraco, W.H.McDowell, and L.J.Tranvik, Plumbing the global carbon cycle: Integrating inland waters into the terrestrial carbon budget, Ecosystems. 10. 2007, 171-184.

[8] A.Frostegard, S.Courtois, V.Ramisse, S.Clerc, and D. Bernillon, Quantification of bias related to the extraction of DNA directly from soils, Applied and Environmental Microbiology. 1999, 5409- 5420.

[9] J.Zhou, M.A.Bruns and J.M.Tiedie, DNA recovery from soils of diverse composition, Applied and Environmental Microbiology. 62. 1996, 316-322.

[10] D.N.Miller, J.E.Bryant, E.L.Madsen, and W.C. Ghiorse, Evaluation and optimization of DNA extraction and purification procedures for soil and sediment samples, 65. 1999, 4715-4724.

[11] C.R. Kuske, K.L. Banton, D.L. Adorada, P.C.Stark, and P.J.Jackson, Small-scale DNA sample preparation method for field PCR detection of microbial cells and spores in soil, Applied and Environmental Microbiology. 64. 1998, 2463-2472

[12] M.I.More, J.B.Herrick, M.C.Silva, W.C.Ghiorse, and E.L.Madsen, Quantitative cell lysis of indigenous microorganisms and rapid extraction of microbial DNA from sediment, Applied and Environmental Microbiology. 60. 1994, $1572-1580$.

[13] E.J.Steig, D.P.Schneider, S.D. Rutherford, M.E.Mann, J.C.Comiso, and D.T. Shindell, Warming of the Antarctic ice-sheet surface since the 1957 International Geophysical Year,457 (7228). 2009, 459-462. 
[14] M. Sagova Mareckova, L.Cermak, J.Novotna, K.Plhackova, J.Forstova, and J. Kopecky, Innovative methods for soil DNA purification tested in soils with widely differing characteristics, Applied and Environmental Microbiology.74. 2008, $2902-7$.

[15] D.Dong, A.Yan, H. Liu, and X. Zhang, Removal of humic substances from soil DNA using aluminium sulphate, Journal of Microbiological Methods. 66. 2006, 217-222.

[16] A.Matsuda, S.Tazumi, T.Kagawa, O.Sekizuka, J.E.Murayama, B.C. Moore, and Millar, Homogeneity of the 16S rDNA sequence among geographically disparate isolates of Taylorella equigenitalis, BMC Veterinary Research. 2. 2006, 1.

[17] J. Handelsman, M.R. Rondon, S.F.Brady, J.Clardy, and R.M.Goodman, Molecular biological access to the chemistry of unknown soil microbes: a new frontier for natural products, Chemistry and Biology. 5. 1998, R245-R249.

[18] M.R.Rondon, R.M.Goodman, and J.Handelsman, The earth's bounty: assessing and accessing soil microbial diversity, TIBTECH. 17. 1999, 403-409.

[19] C.L.Roose Amsaleg, S.E.Garnier, and M.Harry, Extraction and purification of microbial DNA from soil and sediment samples, Applied Soil Ecology. 18. 2001,47-60.

[20] Y.Tsai, and B.H.Olson, Rapid method for separation of bacterial DNA from humic substances in sediments for polymerase chain reaction, Applied and Environmental Microbiology. 58. 1992, 2292-5.

[21] P.R.Robe, C.Nalin, T.M.Capellano, P.Vogel, and Simonet, Extraction of DNA from soil, European Journal of Soil Biology. 39. 2003, 183-190.

[22] J .E.Stach, S.Bathe, J.P.Clapp, and R.G.Burns, PCR-SSCP comparison of 16S rDNA sequence diversity in soil DNA obtained using different isolation and purification methods., FEMS Microbiology Ecology. 36. 2001, 139-151.

[23] C.C.Tebbe, and W.Vahjen, Interference of humic acids and DNA extracted directly from soil in detection and transformation of recombinant DNA from bacteria and yeast .59. 1993, 2657-2665. 